\title{
ПРИНЦИП СПРАВЕДЛИВОСТІ ТА ЙОГО РЕАЛІЗАЦІЯ КОНСТИТУЦЙНИМ СУДОМ УКРАЇНИ ПІД ЧАС ЗДІЙСНЕННЯ ПРАВОСУДДЯ
}

Вступ. Сьогодні Україна знаходиться у складних умовах. Пандемія коронавірусу COVID-19 та обмеження прав людини під час загальнодержавного карантину, війна на Сході України, складна економічна ситуація призводять до того, що питання справедливості є особливо актуальним. Після Революції Гідності у суспільстві виник запит на справедливість. Сприяти їі забезпеченню повинен Конституційний Суд України, оскільки справедливість є основоположним принципом функціонування держави.

Важливою проблемою у праві є правове регулювання та правозастосування принципів права, які відіграють важливу роль, оскільки визначають головні ознаки права, шляхи його розвитку та удосконалення.

На загальнотеоретичному рівні принципи права у своїх працях досліджували такі видатні науковці, як С.С. Алексєєв, М.І. Козюбра, А.М. Колодій, С.П. Погребняк, П.М. Рабінович.

Постановка завдання. Метою статті є аналіз практики застосування принципу справедливості Конституційним Судом України, який у своїх рішеннях розкриває його зміст. На нашу думку, питання розуміння принципу справедливості органами конституційної юстиції не достатньо вивчено та проаналізовано науковцями.

Результати дослідження. Як справедливо зазначає А.М. Колодій: «Будь-які принципи, у тому числі й принципи права, є продуктом людської діяльності, результатом якої вони виступають та інтереси якої вони задовольняють. Принципи є соціальними явищами як за джерелом виникнення, так і за змістом: їх виникнення зумовлюється потребами суспільного розвитку й у них відображаються закономірності суспільного життя. Головними джерелами цих принципів є політика, економіка, мораль, ідеологія, соціальне життя» [1, с. 42].

Забезпечення справедливості, права на справедливий суд є показником демократичності держави. Головна мета правосуддя полягає саме у забезпеченні справедливості. Важливу роль принцип справедливості відіграє тоді, коли є прогалини у законодавстві. Зростає його роль, коли судді потрібно застосувати не аналогію закону, а аналогію права. Справедливість є і моральною категорією. Тому, як застосує іï суддя під час вирішення спору, залежить і від його моральних якостей, правової культури і правосвідомості, усвідомлення своєї відповідальності перед сторонами.

Конституційний Суд України як єдиний орган конституційної юрисдикції забезпечує верховенство Конституції України, що є стрижнем усіх повноважень Конституційного Суду України.

O.І. Махніцький зазначає: «Захищаючи Конституцію, в якій відтворено морально-правові цінності, Конституційний Суд України захищає право і такі соціальні пріоритети: народ, який є джерелом влади; права і свободи людини і громадянина;

(C) Н. В. Шелевер, 2020 
суверенітет і цілісність території; демократична влада і судовий контроль; рівність кожного громадянина перед законом та інші. Реалізація принципу верховенства права у конституційному судочинстві відкриває шлях до творчого застосування закону. Рішення Конституційного Суду України, засновані на принципі верховенства права, за змістом мають утверджувати права та свободи людини, укріплювати довіру не лише до самого Конституційного Суду України, а й у його особі до всіх державних інституцій» [2, с. 42].

У Конституції України принцип справедливості не закріплений у прямій формі. Проте практика Конституційного Суду України свідчить про сприйняття його правовою системою. Уся правова система грунтується на ідеї справедливості.

Конституційний Суд України у своїх рішеннях розкриває суть принципу справедливості, вказуючи тим самим на його унікальну роль. Як зазначається у рішенні Конституційного Суду України від 2 листопада 2004 року № 15-рп/2004 року у справі за конституційним поданням Верховного Суду України щодо відповідності Конституції України (конституційності) положень статті 69 Кримінального кодексу України (справа про призначення судом більш м’якого покарання): «Справедливість - одна з основних засад права, є вирішальною у визначенні його як регулятора суспільних відносин, одним із загальнолюдських вимірів права. Зазвичай справедливість розглядають як властивість права, виражену, зокрема, в рівному юридичному масштабі поведінки й у пропорційності юридичної відповідальності вчиненому правопорушенню.

У сфері реалізації права справедливість проявляється, зокрема, у рівності всіх перед законом, відповідності злочину і покарання, цілях законодавця і засобах, що обираються для їх досягнення.

Окремим виявом справедливості є питання відповідності покарання вчиненому злочину; категорія справедливості передбачає, що покарання за злочин повинно бути відповідним злочину. Справедливе застосування норм права - є передусім недискримінаційний підхід, неупередженість. Це означає не тільки те, що передбачений законом склад злочину та рамки покарання відповідатимуть один одному, а й те, що покарання має перебувати у справедливому співвідношенні із тяжкістю та обставинами скоєного і особою винного. Адекватність покарання ступеню тяжкості злочину випливає з принципу правової держави, із суті конституційних прав та свобод людини і громадянина, зокрема права на свободу, які не можуть бути обмежені, крім випадків, передбачених Конституцією України» [3].

Справедливість є конституційною засадою судочинства. Про це йдеться у рішенні Конституційного Суду України від 30 січня 2003 року №3-рп/2003 у справі про розгляд судом окремих постанов слідчого і прокурора: «Правосуддя за своєю суттю визнається таким лише за умови, що воно відповідає вимогам справедливості і забезпечує ефективне поновлення в правах. Загальною декларацією прав людини 1948 року передбачено, що кожна людина має право на ефективне поновлення в правах компетентними національними судами у випадках порушення ії основних прав, наданих їй конституцією або законом (стаття 8). Право на ефективний засіб захисту закріплено також у Міжнародному пакті про громадянські та політичні права (стаття 2) і в Конвенції про захист прав людини та основних свобод (стаття 13)» [4]. 
Проблемним питанням є те, що в Україні судовий процес не завжди є справедливим, що призводить до оскарження рішень національних судів до Європейського Суду з прав людини. Інколи під час розгляду справи суддя бачить, що і закон, який підлягає застосуванню у спірних правовідносинах, не є справедливим.

У рішенні Конституційного Суду України від 11 жовтня 2005 року № 8-рп/2005 у справі про рівень пенсії і щомісячного довічного грошового утримання зазначається, що діяльність правотворчих і правозастосовних органів має здійснюватися за принципом справедливості [5].

Конституційний Суд України у своєму рішенні від 22 вересня 2005 року № 5-рп/2005 у справі про постійне користування земельними ділянками зазначає, що «із конституційних принципів рівності і справедливості випливає вимога визначеності, ясності і недвозначності правової норми, оскільки інше не може забезпечити іï однакове застосування, не виключає необмеженості трактування у правозастосовній практиці і неминуче призводить до сваволі» [6].

У рішенні від 04 червня 2019 року № 2-р/2019 Конституційний Суд України досліджував можливість обмеження конституційних прав і свобод та висловив думку про те, що обмеження щодо реалізації конституційних прав і свобод не можуть бути свавільними та несправедливими. Суд звертає увагу і на те, що «...у разі регулювання соціальних прав із метою забезпечення соціальної справедливості застосування принципу абсолютної рівності може спричинити ситуацію, за якої внесення змін до будь-яких нормативно-правових актів (щодо прав та обов'язків осіб) буде неможливим, та створити загрозу економічній безпеці держави (призвести до негативних фінансових наслідків)» [7].

У рішенні від 20 червня 2007 року № 5-рп/2007 Конституційний Суд України розкриває сутність справедливості через принцип розмірності, або пропорційності. У рішенні зазначається: «Тому розмірність (пропорційність) обмеження прав кредиторів суб'єктів господарювання у комунальному секторі економіки на задоволення своїх вимог у провадженні у справах про банкрутство має визначатися відповідно до встановлених принципів справедливості» [8].

Часто у своїх рішеннях Конституційний Суд України вказує на порушення принципу справедливості. Згідно з рішенням Конституційного Суду України від 18 лютого 2020 року № 2-р/2020 у справі за конституційним поданням Верховного Суду України усі судді у відставці, незалежно від того, коли вони пішли у відставку, і пройшли чи не пройшли кваліфікаційне оцінювання, повинні мати однакове грошове забезпечення для судді у відставці. Якщо людина на момент набуття чинності закону про судоустрій і статус суддів мала вік 65 років, при досягненні якого судді йдуть у відставку, то вона фізично не могла виконати вимоги закону про проходження кваліфікаційного оцінювання. Після цього треба було ще пропрацювати три роки. Тому в цій частині порушується принцип рівності та справедливості [9].

Висновки. На підставі аналізу позицій Конституційного Суду України можна зробити висновок, що метою діяльності держави є досягнення справедливості у всіх сферах суспільного життя. Справедливість є складником принципу верховенства права. Найвищою соціальною цінністю є права, свободи та інтереси людини, які повинні бути захищені справедливим судом. Суд повинен стати гарантом справедливості, і це ми можемо побачити на підставі позицій Конституційного Суду України. 
На підставі розглянутих рішень Конституційного Суду України робимо висновок, що принцип справедливості активно застосовується ним під час вирішення справ. Принцип справедливості стає у судовій практиці нормою прямої дії. Реалізовуючи цей принцип, Конституційний Суд України забезпечує рівність всіх перед законом і судом та судовий захист конституційних прав і свобод людини та громадянина.

\section{Jimepamypa}

1. Колодій А.М. Принципи права: ґенеза, поняття, класифікація та реалізація. Альманах права. 2012. Вип. 3. С. $42-46$.

2. Махніцький О.І. Застосування та інтерпретація принципу верховенства права у конституційному правосудді. Наукові праці Національного університету "Одеська юридична академія». 2013. T. 13. C. 41-49.

3. Рішення Конституційного Суду України у справі за конституційним поданням Верховного Суду України щодо відповідності Конституції України (конституційності) положень статті 69 Кримінального кодексу України (справа про призначення судом більш м'якого покарання) № 15-рп/2004 від 2 листопада 2004 року. URL: http://www.ccu.gov.ua/docs/504 (дата звернення: 15.07.2020).

4. Рішення Конституційного Суду України у справі за конституційним поданням Верховного Суду України щодо відповідності Конституції України (конституційності) положень частини третьої статті 120 , частини шостої статті 234 , частини третьої статті 236 Кримінально-процесуального кодексу України (справа про розгляд судом окремих постанов слідчого і прокурора) № 3-рп/2003 від 30 січня 2003 року. URL: http://www.ccu.gov.ua/docs/470 (дата звернення: 20.07.2020).

5. Рішення Конституційного Суду України у справі за конституційними поданнями Верховного Суду України та 50 народних депутатів України щодо відповідності Конституції України (конституційності) положень абзаців третього, четвертого пункту 13 розділу XV «Прикінцеві положення» Закону України «Про загальнообов'язкове державне пенсійне страхування» та офіційного тлумачення положення частини третьої статті 11 Закону України «Про статус суддів» (справа про рівень пенсії і щомісячного довічного грошового утримання) № 8-рп/2005 від 11 жовтня 2005 року. URL: http://www.ccu.gov.ua/docs/519 (дата звернення: 22.07.2020).

6. Рішення Конституційного Суду України у справі за конституційним поданням 51 народного депутата України щодо відповідності Конституції України (конституційності) положень статті 92, пункту 6 розділу $\mathrm{X}$ «Перехідні положення» Земельного кодексу України (справа про постійне користування земельними ділянками) № 5-рп/2005 від 22 вересня 2005 року. URL: http://www.ccu.gov.ua/ docs/516 (дата звернення: 24.07.2020).

7. Рішення Конституційного Суду України у справі за конституційними поданнями 45 народних депутатів України щодо відповідності Конституції України (конституційності) окремих положень Закону України «Про пенсійне забезпечення» та 48 народних депутатів України щодо відповідності Конституції України (конституційності) окремих положень законів України «Про пенсійне забезпечення», «Про статус і соціальний захист громадян, які постраждали внаслідок Чорнобильської катастрофи», «Про пенсійне забезпечення осіб, звільнених з військової служби, та деяких інших осіб», «Про державну службу», «Про судову експертизу», «Про Національний банк України», «Про службу в органах місцевого самоврядування», «Про статус народного депутата України», «Про дипломатичну службу», «Про загальнообов'язкове державне пенсійне страхування», «Про Кабінет Міністрів України», «Про прокуратуру», а також Положення про помічника-консультанта народного депутата України, затвердженого Постановою Верховної Ради України від 13 жовтня 1995 року № 379/95-ВР №2-р/2019 від 04 червня 2019 року. URL: http://www.ccu.gov.ua/sites/default/files/docs/2_p_2019_0.pdf (дата звернення: 25.07.2020).

8. Рішення Конституційного Суду України у справі за конституційним зверненням відкритого акціонерного товариства «Кіровоградобленерго» про офіційне тлумачення положень частини восьмої статті 5 Закону України «Про відновлення платоспроможності боржника або визнання його банкрутом» (справа щодо кредиторів підприємств комунальної форми власності) № 5-рп/2007 від 20 червня 2007 року URL: http://www.ccu.gov.ua/docs/552 (дата звернення: 25.07.2020).

9. Рішення Конституційного Суду України у справі за конституційним поданням Верховного Суду України щодо відповідності Конституції України (конституційності) окремих положень пунктів 4, 7 , $8,9,11,13,14,17,20,22,23,25$ розділу XII «Прикінцеві та перехідні положення» Закону України «Про судоустрій і статус суддів» № 1402-VIII від 2 червня 2016 року URL: http://www.ccu.gov.ua/ dokument/2-r2020 (дата звернення: 27.07.2020). 


\section{Анотація}

Шелевер Н. В. Принцип справедливості та його реалізація Конституційним Судом України під час здійснення правосуддя. - Стаття.

В умовах пандемії коронавірусу COVID-19, війни на Сході України, економічної кризи актуальним питанням сьогодення є дослідження справедливості як загального конституційного принципу. Забезпечувати його реалізацію на практиці повинен Конституційний Суд України як орган конституційної юрисдикції. Автор у своїй статті проаналізував практику застосування принципу справедливості Конституційним Судом України, бо саме у його рішеннях і розкривається зміст цього принципу. Метою правосуддя є забезпечення справедливості. Адже саме в судах і шукають справедливість. Принцип справедливості відіграє важливу роль у тому разі, коли судді треба застосувати не аналогію закону, а аналогію права. Як застосовує цей принцип на практиці суддя, залежить від його моральних якостей, правової культури і правосвідомості. Хоча у Конституції України принцип справедливості не закріплений у прямій формі, проте уся правова система грунтується на ідеї справедливості. Про це свідчить практика Конституційного Суду України. У своїх рішеннях Конституційний Суд України розкриває суть принципу справедливості. Справедливість є конституційною засадою судочинства. Проте проблемою в Україні є те, що судовий процес не завжди справедливий, і це зумовлює звернення до Європейського суду з прав людини. Конституційний Суд України звертає увагу і на те, що діяльність правотворчих і правозастосовних органів повинна здійснюватися за принципом справедливості. Єдиний орган конституційної юрисдикції досліджував і можливість обмеження конституційних прав і свобод. На його думку, таке обмеження щодо реалізації конституційних прав і свобод не може бути свавільним і несправедливим. Конституційний Суд України розкриває сутність справедливості через принцип розмірності, або пропорційності. У своїх рішеннях Конституційний Суд України вказує і на порушення принципу справедливості. Справедливість є складником принципу верховенства права. Оскільки права, свободи та інтереси людини є найвищою соціальною цінністю, то саме справедливий суд повинен їх захищати. Конституційний Суд України застосовує принцип справедливості під час здійснення правосуддя і він стає нормою прямої дії.

Ключові слова: принципи права, справедливість, право, держава, суд, верховенство права, судова практика.

\section{Summary}

Shelever $N . V$. The principle of justice and its implementation by the Constitutional Court of Ukraine when administering justice. - Article.

In a pandemic coronavirus COVID-19, the war in the East, the economic crisis pressing issue of our time is the study of justice as a General constitutional principle. To ensure its implementation in practice, the constitutional Court of Ukraine should act as a body of constitutional jurisdiction. The author in his article has analyzed the practice of application of the principle of justice the Constitutional Court of Ukraine, because in its decisions there is the content of this principle. The purpose of justice is to secure justice. After all, everyone seeks justice in the courts. The principle of justice plays an important role in the case when the judge must apply not the analogy of law but the law of analogy. As applies this principle in practice, the judge depends on his moral qualities, legal culture and legal consciousness. Although the principle of fairness is not fixed explicitly in the Constitution, the whole legal system is based on the idea of justice. This is evidenced by the jurisprudence of the constitutional Court of Ukraine. In its decisions the constitutional Court of Ukraine reveals the essence of the principle of justice. Justice is a constitutional principle of justice. However, the problem in Ukraine is that the court process is not always fair and this determines the appeal to the European court of human rights. The constitutional Court of Ukraine drew attention to the fact that the activities of law-making and enforcement bodies should be carried out according to the principle of fairness. The only body of constitutional jurisdiction investigated and the possibility of limiting constitutional rights and freedoms. In his opinion such restrictions on the exercise of constitutional rights and freedoms cannot be arbitrary and unfair. The constitutional Court of Ukraine reveals the essence of justice through the principle of dimensionality or proportionality. In its decisions the constitutional Court of Ukraine points to the violation of the principle of justice. Justice is a component of the rule of law. Since the rights, freedoms and interests of man are the highest social value, it is a fair trial should protect them. The constitutional Court of Ukraine applies the principle of fairness in the administration of justice and it becomes the norm.

Key words: principles of law, justice, the law, state, court, rule of law, judicial practice. 